\title{
Lawyers Doing Philosophy
}

\author{
Pauline Westerman
}

\section{Introduction}

Kristen Rundle's paper can be understood as an attempt not only to combine Fuller's and Arendt's approach, but to use their insights to 'develop a distinctive project of normative legal theory concerned with law's public aspect, which pivots on the status of persons within the legal frame. ${ }^{1}$ It seems to me that Rundle hopes to find building blocks for the view that the law cannot be identified with the commands of a sovereign, but should be understood as a kind of living law, to use Ehrlich's term, ${ }^{2}$ as something that originates from 'below,' and which is based on the expectations and experiences of the human actors who both make and are guided by that law.

I will first give an internal critique on Rundle's enterprise and address the question of whether and to what extent the writings of Fuller and Arendt can indeed be used to construct such an alternative jurisprudence 'targeted at overthrowing the command conception of law'3 (section 2). I shall then take up a point of view that is more external to Rundle's enterprise and will question the merits of Rundle's approach as such (section 3). Finally, I will consider why Rundle's approach is as it is and attribute its specific characteristics to her legal background (section 4).

\section{Spatial metaphors ${ }^{4}$}

There is much to be said for the view that Fuller starts his analysis of law by emphasizing the role of customary law, the mutual expectations of citizens and the interaction between citizen and government. His criticism of a command view of law is well-known. This emphasis is especially clear when he addresses the question of how we can account for the obligatory force of law, especially contracts. Unlike Hart, who distinguished sharply between habits and rules on the basis that rules but not habits have normative force, Fuller did not assume such a strict separation. On the contrary, he wanted to explain how obligations could be created and therefore struggled with the question of how customs could give rise

1 Kristen Rundle, 'Legal Subjects and Juridical Persons: Developing Public Legal Theory through Fuller and Arendt,' this volume, 219.

2 Eugen Ehrlich, Grundlegung der Soziologie des Rechts (München/Leipzig: Duncker \& Humblot, 1913).

3 Rundle, 'Legal Subjects and Juridical Persons', 217.

4 Editorial comment: In an earlier version of her paper, Rundle used the term 'bottom-up jurisprudence' to describe her aims. 
to obligations. Under which conditions does the statement 'A regularly performs action $\mathrm{x}$ ' turn into the statement 'A should perform action $\mathrm{x}$ '?

His answer to this question is well-known: it is only if I order my own actions in anticipation of the other's habitual behaviour, only if I orient myself to the recurrence of the other's action, that I am justified to criticize him if he breaks his habit. The mere fact that my neigbour habitually walks to town is in itself not a reason for me to blame him if one day he does not go there. But if he usually brings groceries for me, an obligation is created. The ground for this obligation is that I ordered my affairs (I did not go to the store myself) in anticipation of his repetitive actions. ${ }^{5}$

Thus, Fuller has an important ('bottom-up', if you like) message to convey about the way in which obligations are created. But this does not mean that he thinks law can only be understood as the result of reciprocal expectations of human agents. Fuller is clearly aware of the fact that once law is there, it in turn structures human actions. In his beautiful essay 'Freedom as a Problem of Allocating Choice, ${ }^{6}$ also referred to by Rundle, he rejects the assumption of the primordial free human agent and emphasizes that freedom is dependent on the amount of alternative choices that are offered by the structure of both language and law. The options that are available in ordering one's life are ultimately dependent on the informed choices that are made by officials in their institutional roles. In fact, Rundle sees this as well. She writes: 'This distinctive species of personhood (...) is (...) [also] dependent on how those commitments [towards that person] are expressed by those who discharge the functions and purposes of the surrounding legal institutional frame.'7 This means that what she calls 'human agency' is the result of the status that is accorded to human beings by the law.

I don't see anything 'bottom-up' here. We might as well say the opposite and claim that Fuller maintained that human agency is constituted by law and therefore dependent on the choices of the legislator.

But probably the whole spatial imagery of top and bottom is inappropriate here. ${ }^{8}$ Putting Austin's theory aside, the much criticized 'source-theories' cannot be seen as top-down either. Hart only tells us that legal rules owe their validity to other (secondary) rules in the system that stipulate the criteria for validity. These secondary rules are not necessarily 'higher.' If a spatial metaphor is needed here at all, it is that of the circle. The law of recognition tells us who is competent to make and to change the rules and the one who makes the rules also has the power to change the rule of recognition. The circularity that is involved in Hart's

5 Lon L. Fuller, 'Two Principles of Human Association,' in The Principles of Social Order: Selected Essays of Lon L. Fuller, ed. and intro. Kenneth I. Winston (Durham, NC: Duke University Press, 1981), 227.

6 Lon L. Fuller, 'Freedom as a Problem of Allocating Choice,' Proceedings of the American Philosophical Society 112(2) (1968): 101-6

7 Rundle, 'Legal Subjects and Juridical Persons', 218.

8 Rundle, 'Legal Subjects and Juridical Persons', 218. 
account is not very different from the circles of interaction mentioned by Fuller. The mutual expectations of $\mathrm{A}$ and $\mathrm{B}$ create the rights and obligations of a contract, and the contract structures the available options for A and B. Thus if Hart deserves criticism, it is not on the ground that his view is too top-down. Moreover, even if we could do so, we cannot revert to Fuller's theory to claim the opposite. Although his picture of law is for a large part based on the consent of contracting parties, this is certainly not the whole story. Obligations are created in a bottom-up manner, but the human agent as a juridical person is created by the law.

What, then, of Hannah Arendt's work? Can we find any building blocks here for the view that law is a product of human agency? I think not. In fact, here the same applies as in Fuller's case. The juridical person is indeed a central concern, but this concept is not used in order to construct a 'bottom-up or alternative jurisprudence.' What is clearly of concern to Arendt is the normative space in which people are accorded rights and obligations. The juridical person is nothing more or less than the legal subject, who can create and change legal reality. Companies are of course also legal persons. The law therefore turns entities into juridical persons. As Hart and Fuller both emphasize, it is the law that structures the possibilities for human beings to act as a legal person. If people are excluded from the normative sphere, they are deprived of this capacity, and Arendt notes that this is usually the first step to further deprivations: the destruction of the moral and finally of the physical person. Here again, the structuring element is the law.

\section{The missing problem}

It appears that the whole talk of human agency has no other purpose than to say that in a just legal system human actors should be capable of making and changing the law. Of course, this normative statement can be illustrated by reference to Fuller and Arendt, but needs to be buttressed by arguments as well. Such a systematic argument is lacking, although we find disparate statements of aims underlying Rundle's desire to construct an alternative jurisprudence. So we may understand Rundle's enterprise as inspired by the idea that only within her alternative jurisprudence are people taken seriously as human beings that are capable of ordering their own affairs. Or, because only in this way the rules can serve both to justify and to criticize law. Or, only in this way human beings are not at risk of being downgraded into instruments of governmental policy-aims. Or, only in this way can obedience to the law be justified by means of a reciprocal duty to obedience, binding citizen and state alike.

I give these alternative readings of Rundle's purpose, because all these elements are mentioned but nowhere is there an explicit statement of her aims or a clear problem statement. What is it that Rundle wants to investigate? We know which sources she wishes to use, what authorities she wishes to invoke, but although Rundle convincingly argues that there are interesting similarities between Arendt and Fuller, the reader is not really informed about the problem Rundle wants to 
address with the help of these authors - besides wanting to create a new type of jurisprudence.

One may object that a problem statement is not necessary in view of the fact that we are dealing here with an idea-historical description rather than with an independent argument. But even if her enterprise could be classified as history of ideas, it fails on this count as well. Histories of ideas necessarily have to deal with the historical context in which the described theories operate and with the questions that were addressed by the authors that are being interpreted. Historians should at all times avoid anachronistic interpretations by attributing to the described authors problems that are ours instead of theirs. It is therefore a cardinal sin for any historian of ideas to attribute to John Locke the purpose of 'establishing political liberalism' or, for that matter, to attribute to Arendt the purpose of developing any kind of jurisprudence. ${ }^{9}$

There is very little attention in Rundle's article to the distinction between her concerns and the concerns of Arendt and Fuller. Not only do we sadly miss an explicit formulation of the problem addressed by Rundle herself, but we are also left in the dark about the questions that were addressed by Fuller and Arendt. And despite the similarities between these two authors, so plausibly demonstrated by Rundle, these questions were rather different. Whereas Arendt wanted inter alia to understand the origins of Nazism and anti-Semitism, Fuller wanted - among other things - to restore customary law to a position as mother rather than bastard son of formal law. From the point of view of a historian of ideas, an analysis that focuses on the answers that are given and fails to point out the specific questions that were addressed is necessarily a truncated one.

If the focus of Rundle's article is on the answers, the theories, and the building blocks handed over by authors who are regarded as indisputable authorities, I think that this emphasis is due to the fact that she is addressing philosophical problems in the same way as legal doctrine.

\section{Legal methods}

Rundle's approach contains a number of elements that are characteristic of legal doctrinal analysis. This may be understandable and defensible as elements of legal scholarship but are shortcomings in a philosophical essay. What do I have in mind?

Defending a normative position on the basis of authoritative sources

Both philosophical and legal texts often set out to defend a certain normative position: they do not differ in this respect. However, for philosophers, the

9 Quentin Skinner, The Foundations of Modern Political Thought (Cambridge: Cambridge University Press, 1992). For the debate on how histories of ideas should be written: Richard Rorty, J.B. Schneewind and Quentin Skinner, eds., Philosophy in History (Cambridge: Cambridge University Press, 1984). 
normative position represents a starting point for further analysis. They may inquire into its assumptions, examine, criticize or justify these assumptions, and arrive at a - tentative - conclusion based on the analytical investigation.

In Rundle's article, her normative point of view is not problematized in the same way. Her position remains unaltered during her exposé. It is only fortified by invoking authorities, who are interpreted in the light of her normative conviction. The normative position is not analysed but supported by referring to the fact that it is maintained by respectable sources.

Invoking authoritative sources is a defensible practice in law. In legal study, one's opinion should be seen as coherent within, or at least as fitting into, the development of legal doctrine. A new interpretation should be presented as an interpretation that 'builds on' the tradition. But for philosophers, Kant's adagium 'sapere aude' is more appropriate. If there is something as progress in philosophy, it is brought about by authors who dare to think for themselves and to formulate independent and new points of view. These points of view can only partially be defended by authoritative sources.

\section{The attempt to reconcile divergent and even opposing positions}

Fuller and Arendt are interpreted as being united in their major concern. They are interpreted and reconstructed in such a way that inconsistencies are removed and a coherent order emerges in which different points of view mutually reinforce each other. Where their theories seem to diverge, they are interpreted as correcting each other's blind spots. For the ordinary, non-legal, historian of ideas this approach is incomprehensible. Both Arendt and Fuller dealt with their own pressing problems in such a clear and eloquent manner that there is certainly no need for anyone to supplement either of the two with the other. It is as if we were to mix a Monet with a Mondrian because Mondrian overlooked the brilliance of colour and Monet did not adequately understood abstract compositions.

This is, again, a very defensible approach to legal material: in legal sources, inconsistencies should be removed in order to enhance the stability and predictability of the legal system. But philosophy, like art, flourishes if opposite views are clearly articulated and well-argued. The quality of philosophy is enhanced by diversity rather than a coherent body of insights.

\section{The absence of an explicit problem statement and an independent theoretical perspective}

As noted above, Rundle does not make explicit the problem she wishes to address. While in most disciplines, including philosophy, such an omission is unforgivable, it is quite common in most legal research. In legal doctrine, the specific question is usually tacitly understood: the whole rationale of legal doctrine is to gain oversight, to give an orderly and coherent account of legislation and case-law, or to interpret the existing material in order to fit a new legal or social development. I have analyzed this omission more fully elsewhere and connected this feature to the idea that an explicit and independent theoretical perspective seems to be lack- 
ing in legal doctrinal research (at least if that legal research is not coupled with a sociological, psychological or economic perspective). ${ }^{10}$

I have argued that the absence of such an independent theoretical perspective can be understood from the fact that for legal researchers, the perspective is formed by the legal system itself. The very terms in which the legal system is described are taken from the legal system itself. The theoretical perspective is, therefore, not independent of the legal system that is described. Legal researchers explore, for example, whether a new piece of legislation accords with the principles of legal certainty and equality; or whether it is compatible with a set of laws in a neighbouring area. Comparative legal research is a borderline case. In examining how other legal cultures deal with a certain problem, the 'problem' itself is usually formulated in terms of one's own legal culture. In so far as this gives rise to distortions ('the' problem is not a problem in neighbouring jurisdictions, or not the same problem), an external perspective is needed. Usually, however, the definition of the situation as given in one's own legal system is taken as the starting point for comparison.

A philosophical analysis, on the other hand, usually starts from a theoretical perspective that is not intrinsically bound up with the legal system that is analysed. There is a difference between the perspective and the subject matter. This enables the philosopher to go beyond the legal terms, to inquire into the justification of legal principles, or the assumptions underlying legal arrangements.

\section{Normative foundations}

As already suggested, the search for coherence is one of the most conspicuous traits of legal research and it is present in Rundle's article as well. A common strategy for constructing coherence and unity is to interpret the various precedents, statutes, regulations and isolated rules as concrete manifestations of underlying and unifying principles. A principle such as 'the polluter pays' justifies the existence of many different rules pertaining to liability in environmental law. The idea that abstract standards unify existing laws and regulations, which would otherwise appear as a bunch of disparate and fragmented do's and don'ts is strongly connected to the idea that that same abstract standard also provides a justificatory reason for these laws and regulations. This can be most fruitful in legal analysis. Not only does it help to bring about some order, but it also helps the legal practitioner to find solutions for cases that are not directly covered by rules. Analogous reasoning is not impossible without unifying principles, as Llewellyn has shown, ${ }^{11}$ but it is helped by the fiction of an underlying foundation of abstract and normative standards.

10 Pauline C. Westerman, 'Open or Autonomous? The Debate on Legal Methodology as a Reflection of the Debate on Law,'in Methodologies of Legal Research: Which Kind of Method for What Kind of Discipline?, ed. Mark van Hoecke (Oxford: Hart Publishing, 2011), 87-110.

11 Karl N. Llewellyn, The Bramble Bush: The Classic Lectures on the Law and Law School, with intro and notes by Steve Sheppard (Oxford: Oxford University Press, 2008). 
I suspect that this is the kind of enterprise Rundle had in mind in invoking the help of our famous authors. Just as legal scholars make sense of a doctrine by enumerating its normative pillars, thus unifying and justifying the set of precedents, statutes and the like, Rundle hopes to erect a normative foundation for the theory of law. The problem is: the theory of law is not the same as law. Theories are not justified nor unified by being grounded in abstract principles, but by precise argument.

I am well aware that this is, at least, my own view ${ }^{12}$ and a matter for debate (which falls outside the scope of this contribution). In fact, this applies to all the black and white sketches I make here about the difference between a legal and a philosophical debate. I contrast legal doctrine with what I myself think is important in philosophy. There are, obviously, also philosophers who do not think for themselves and engage in endless interpretations and reinterpretations of the great forerunners, as there are also foundationalist philosophers. I nonetheless would still regard these as weaknesses of a philosophical approach, whereas the same features may be of vital importance for the study of law.

\section{Conclusion}

Both the content as well as the nature of Rundle's article seems to me ill-guided. Despite the amount of careful reading and interpretation that is present in her paper, the sources that are intelligently read and her nuanced style of writing, despite the fact that there are indeed many interesting similarities to be found between Arendt and Fuller and despite the fact that both these authors address very important questions, I would have liked Rundle to have taken on the job herself.

I would look forward to Rundle's own account of how a minimal legality hangs together with the rule of law, or how human rights should be presupposed in a political system that is under the rule of law, or whatever problem she wants to tackle. Yet this kind of independent research can only be carried out if one is prepared to question one's own normative positions as well as those of the great forerunners, if both one's own theoretical perspective as well as that of others are made explicit, and if tensions are fully articulated. If research is conducted in such a way even a search for normative foundations can be enlightening. This kind of research can in my view only materialize if legal methodology is not transplanted into philosophical inquiry. 